\title{
On the Philosophical Works of P. D. Iurkevych ${ }^{1}$
}

\author{
Vladimir Solov'ev \\ Translated from Russian by Richard Hantula
}

$\mathbf{I}_{\mathrm{f}}$

f the importance of genuine thinkers is determined by the loftiness and freedom of their thought and by the inner tone of their ideas rather than by the number and size of the books they have written, then a place of indisputable honour among them must belong to the late professor at Moscow University, Pamfil Danylovych Iurkevych. His intellectual independence and breadth of views were united in remarkable fashion with a sincere recognition of historical tradition, and a profound heartfelt sympathy with life's essential interests was combined with a subtle perspicacity of critical thought. The philosophical works he left are neither numerous nor voluminous. Like many gifted Russians, he did not consider it necessary or possible to give full outward expression to all his intellectual substance or to turn it inside out for display. He did not wish to translate himself into a book or to transform all his spiritual essence into public property. From what he left, however, it is sufficiently clear that we are dealing with a strong and independent mind. Before turning to a survey of his works, I shall give some biographical information about him.

Pamfil Danylovych Iurkevych was the son of a village priest in the Poltava gubernia. He was born about 1827. After completing the seminary in Poltava, he entered the Kyiv Theological Academy in 1847. There he graduated with honours and was assigned by the Academic Conference to the post of preceptor for the class of philosophical sciences; he was confirmed in that position by a special order of the local authorities (1851). In the following year Iurkevych was awarded a master's degree and became one of the academy's assistant professors. "For his outstandingly zealous and very useful labours he was awarded the commendation of the Holy Synod" in 1853. The following year he was made an assistant inspector of the academy. The position, however, was probably not to his liking, for two years later he was released from it at his own request. Besides philosophy, he was entrusted in 1857 with the teaching of German. In a year he was promoted to the rank of associate professor. In 1861 he

\footnotetext{
1 The article was first published in Zhurnal Ministerstva narodnogo prosveshcheniia, vol. CLXXVI, Dec. 1874, pp. 294-318. Bibliographic references have been reformatted according to MLA, as per EWJUS's style guidelines.
} 
was promoted to the rank of full professor "by decision of the Holy Synod for his exemplarily zealous service, extensive knowledge, and excellent teaching." His writings, some of which were published in the academy's scholarly journal, attracted a broader attention than that of the ecclesiastical authorities. Also in 1861, Iurkevych was offered the chair of philosophy at the University of Moscow. Having received the sovereign's assent, he became a full professor there in October of that year. In Moscow, besides his classes at the university, he delivered a number of public lectures on materialism and later taught pedagogics for several years at the teachers' college of the Ministry of War. ${ }^{2}$ From 1869 to 1873 he was chairman of the Department of History and Philology. In the latter year Pamfil Danylovych lost his wife (he had married in Kyiv in 1856); she died in the Crimea after a long illness. This misfortune and the anxieties associated with it utterly ruined Pamfil Danylovych's health. He fell seriously ill and did not recover. On 4 October [16 October N.S.], 1874, he passed away from exhaustion in Moscow.

Iurkevych's philosophical works were partly published in a provincial, moreover, specifically ecclesiastical journal. They are little known even to individuals who might appreciate their value. What follows is intended as an introduction to these articles.

Iurkevych's first printed work was, so far as I know, the article "Serdtse i ego znachenie v dukhovnoi zhizni cheloveka" ("The Heart and Its Significance in Man's Spiritual Life," 1860). ${ }^{3}$ The article is of considerable philosophical interest, and so I shall provide a detailed account of it, for the most part using the author's own words.

The entity of man, with respect to body and soul, is commonly thought of as consisting of two most important basic parts, which in ordinary language are designated by the words heart and head. Beyond question, for the general living language these words, although strictly speaking they designate parts of the physical organism, refer at the same time chiefly to the two chief aspects of the spiritual essence. Such a usage presupposes a common recognition that specific elements of the spiritual essence have their immediate expression or embodiment in specific parts of the corporal organism. More precisely, the moral or practical element of the spirit, that

\footnotetext{
2 Pedagogics was one of Pamfil Danylovych's favourite pursuits. He devoted two large works to it. It would be desirable for competent individuals to evaluate the true worth of these writings.

3 The article is not signed.
} 
is, the principle of the will and the soul's affects, is embodied directly in the heart as the central organ of the circulatory system. The theoretical principle of the spirit, that is, the mind, has its external expression in the head as the vessel for the most important parts of the nervous system, namely the brain and the organs of the external senses. Thus, according to this point of view, the human entity, as human, consists not of the soul and body as two substantial parts, but of the heart and the mind as two soulbody aspects of one concrete essence. But the viewpoint under consideration does not ascribe identical significance in the general human entity to these two aspects or elements. This can be seen from relevant passages of the Bible, which we may consider the most ancient monument expressing not a personal consciousness but that common to a whole people.

According to the Bible, the heart is the keeper and carrier of all bodily forces and the focus of the entire life of man's soul and spirit. In the heart there are rooted not only the soul's diverse feelings, anxieties, passions, and moral states; all the body's cognitive acts as well have not the mind as such but the heart as their deepest foundation. Meditation, according to the Bible, is the suggestion or counsel of the heart. To comprehend with the heart means to understand. To know with all one's heart is to understand totally. As the focus of all man's corporal and diverse spiritual life, the heart

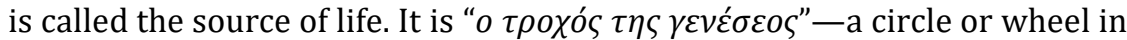
whose rotation all our life lies. That is why it constitutes the deepest part of our being: "man's heart is deepest of all, and who can know it?" The state of the heart expresses the entire state of the soul, but external displays of word, thought, and deeds never exhaust this source.

Supposing the focus of man's spiritual life to be in the heart, the biblical writers acknowledged the head as the visible tip, as it were, of the life that is originally and directly rooted in the heart. Many passages in the Bible, however, express the absolutely definite idea that the head plays the role of an intermediate organ between the integral entity of the soul and the influence it experiences from without or from above, and that at the same time it is fitted for governance in the integral system of the soul's acts. These phenomena of the soul's activity in the head still do not exhaust the entity of the soul. Because of the necessity of thought we must assume a certain original spiritual essence that requires the above-mentioned intermediacy and governance of the head. It is this original spiritual essence that, according to the Bible, has as its immediate organ the heart. Thus the heart is acknowledged not only as the embodiment of one aspect of our spirit but at the same time as the expression of the deepest basis of the entire spiritual entity. One need not search far: a good example of such a relation can be found in the sphere of the body. Thus, the blood is one of the liquid parts of the living body and at the same time is the general 
substratum or plasma of the entire body in all its parts, inasmuch as the body's parts develop from the nutriments of the blood. The very thing that "actualiter" [in actuality] is only a part of is at the same time the original basis of the whole.

What relation does the significance that common consciousness and the Bible attribute to the heart and head have to the tenets of scientific philosophy? On the basis of unquestionable physiological facts, psychology teaches that the head, or the brain and the nerves going to it, serves as the soul's necessary and direct corporal organ for the formation of representations and thoughts from the impressions of the external world; or that only this organ is a direct conductor and carrier of the soul's actions. A particular viewpoint concerning the entity of the human soul was long associated in psychology with this unarguably true doctrine of the corporal organ of the phenomena of the soul. To a certain degree, however, that viewpoint was able to develop separately and independently. When the nerves centred in the head are put into motion by influences and impressions of the external world, the direct and immediate consequence of that movement is the appearance in the soul of representations, concepts, or knowledge of the external world. From this it was easy to arrive at the supposition that the essential capability of the human soul was precisely this capability to give birth to or form representations about the world on the occasion of the movement of nerves excited by an external object. It turns out that what exists in the nerves as movement occurs and exists in the soul as representation. Accordingly, there long prevailed, and to this day there still partly prevails in philosophy, the view that the human soul is originally a representing entity; that thought is the very essence of the soul; or that thought constitutes the entire spiritual man. The will and the feelings of the heart were understood as phenomena, modifications, and accidental states of thought. Given these definitions, it would be utterly incongruous to think that there is something intimate in the soul itself, a deep essentiality that is never exhausted by the phenomena of thought. So, for once we can see here at least an inclination toward an elucidation of phenomena that does not attribute to essence greater and more significant content than to its phenomena, which are accessible to our observation. He who thinks on the contrary that in the human soul, as in all that exists, there are aspects inaccessible to relative cognition, can already see in advance the great significance of the biblical doctrine of the deep heart, whose secrets are known only to the divine mind.

It is obvious that a philosophy based on the proposition that the essence of the soul is thought and nothing more must deny all that is essentially moral in men. It replaces the vital commandment of love (a commandment so significant for the heart) with an abstract sense of duty, a sense that presupposes not fervour or heartfelt attraction to the good but a 
simple indifferent understanding of phenomena. Similarly, insofar as our knowledge of God is anthropomorphous, this philosophy necessarily arrives at an abstract concept of the essence of God and defines all the richness of the divine life as an idea, as a thought that establishes a world without will or love out of logical necessity alone. There is no question, however, that thought does not exhaust all the fullness of human spiritual life, just as perfection of thought still does not define all the perfections of the human spirit. He who asserts that thought is the entire man and hopes to explain all the diversity of the soul's phenomena as deriving from thought will be no more successful than the physiologist who would explain the phenomena of hearing-sounds, tones, and words-as deriving from phenomena of vision, such as extension, shape, and colour. Accordingly, we can now assume that the activity of the human spirit has as its direct organ in the body not only the head or the brain with the nerves going to it but stretches much farther and deeper within the corporal organism. As is the case with the essence of the soul, the connection of the soul with the body must be much richer and more diverse than is commonly thought. This notion of the many-sided, not one-sided, connection of the soul with the body, which is, of course, general and as yet indefinite, is contained in the biblical doctrine of the heart as the direct and immediate organ of the activities and states of the soul. The soul's corporal organ can be nothing other than the human body. That is why, since the heart combines all the body's powers, the heart serves as the direct organ of the soul's life. The body is an expedient organ for the soul, not in one of its parts but in its entire makeup and organization.

The proposition that actions of the soul, namely the soul's conscious activity, have their direct organ in the brain was earlier said to have been proved by unquestionable physiological facts. There follows from those facts, however, very little for the psychological doctrine of the residence of the soul in the body. We can only say that the activity or, more precisely, the movement of the brain, is a necessary condition for the soul to be able to give birth to sensations and representations of the world; or that the movement communicated to an organ must be propagated to the brain in order to become a sensation of the soul and a representation. If from this it is further concluded that the soul by its essence must reside in the brain, that hypothesis is based on extraneous observations taken from the sensible world. In that world, as soon as two members of an interaction are observable by us, they are equally sensible; movement passes from one of them to the other by means of a pressure or an impetus. The moving body must exert a pressure or an impetus spatially on the body being moved, which thereupon develops in itself some form of motion. But this pressure or impetus is impossible in the interaction between the soul and the body, where one member is the non-spatial entity of the soul. The soul lacks a 
spatial aspect to receive an impetus from the spatial movement of the brain. Therefore, although the activity of the brain is a necessary condition for the soul being able to give birth to sensations and representations, this does not imply the unthinkable hypothesis that the soul must reside in the brain for this purpose. The connection between the movement of a certain part of the brain and the representation thereupon formed by the soul is not a mechanical connection of pressure and impetus that unquestionably would presuppose the spatial compatibility of the connected members. Rather, it is an expedient and ideal connection.

These observations show that the most trustworthy facts of physiology, which confirm the close connection of the conscious life of the soul with the activity of the brain, do not contradict the common consciousness and the biblical doctrine of the heart as the true focus of the soul's life. It is quite possible that the soul, as the basis of the conscious psychic phenomena known to us, has the heart as its immediate organ, although its conscious life requires the activity of the brain for its manifestation.

At the present time, physiology knows that the heart is not a simple muscle or an insensible mechanism that merely controls the movement of blood in the body through mechanical pressure. Two very remarkable orders of nerves are united in the heart: the so-called sympathetic nerves that control all the vegetal functions of the organism, and the nerves that serve as necessary organs of sensation or representation and arbitrary action. It can be said that in the heart, which is a well of blood, the two nervous systems - the true body of a creature that has a soul-come together and interpenetrate in a unity and interaction that is not exhibited by any other organ of the human body. Can we not say, without contradicting the facts of physiology, that all the most important systems of the human organism have in the heart a representative, one that looks after their preservation and life from that focus? But from this it at least becomes clear why the general feeling of the soul, or the feeling we have of our own spiritual and corporal being, makes itself apparent in the heart, with the result that the most imperceptible changes in this feeling are accompanied by changes in the beating of the heart. At the same time, the moods and dispositions of the soul, which are determined by its general feeling, are the final and deepest bases for our thoughts, desires, and deeds. While physiology points out in the brain the physical conditions on which the activity of the soul depends, the biblical doctrine of the heart as the birthplace of human thoughts, desires, and deeds indicates to us the immediate spiritual and moral source of the soul's activity in the integral and indivisible mood and disposition of the entity of the soul. Our thoughts, words, and deeds are originally not images of external things but images or expressions of the general feeling of the soul, results of our mood at heart. 
Of course, in ordinary life, which is filled with worries about current reality, we pay too little attention to this intimate side of our thoughts and acts. Nonetheless, it remains true that everything that enters the soul from without, through the intermediary of the sense organs and the brain, is recast and changed, and receives its final and constant quality according to the soul's particular, individually determined mood at heart. Conversely, no actions or excitations coming from the external world can evoke representations or feelings in the soul if they are incompatible with the man's mood at heart. In man's heart there lies the basis for the fact that his representations, feelings, and acts acquire a singularity in which his soul, and not another's, is expressed; or that they take on a personal, individually determined direction because of which they are expressions not of a general spiritual essence but of a discrete, living, truly existent man.

In inner experiences we do not at all notice how the brain is affected by changes in our thoughts, wishes, and feelings. On the basis of direct introspection we would not even know that it was the organ of the conscious soul. If the relation between thought and its organ has reasonable basis in the purpose of thought, which in itself must be a calm and indifferent consciousness of the reality surrounding us, it still follows that neither in thought nor in its corporal organ does the soul show itself in all the indivisibility and fullness of its essence. If man revealed himself by thought alone, which in such a case would in all probability be a most authentic image of external objects, then the diverse world, rich with life and beauty, would unfold before his consciousness as a correct but lifeless mathematical quantity. He could have complete and thorough insight into the quantity, but he would no longer encounter anywhere a true and vital existence that would stimulate him by its beauty of forms, mysterious attractions, and infinite fullness of content. Such one-sided thinking does not exist in a true soul. What would become of man if his thought had no purpose other than to repeat in its movements the events of reality, or to reflect in itself phenomena extraneous to the spirit? In that case our thoughts would perhaps be distinguished by the same definiteness as mathematical quantities, but we would be able to proceed only in breadth and not in depth in our knowledge of things. The finest philosophers and the great poets recognized that their heart was the true birthplace of the profound ideas they imparted to mankind. Consciousness, whose activity was associated with the functioning of the sense organs and the brain, contributed to those ideas merely the clarity and definiteness characteristic of thought.

The essence of the soul cannot be encompassed by a superficial glance; the soul develops not only in time but also in eternity. The soul's essence cannot be determined from only those of its states that are evoked by impressions of the external world. There will always remain in the soul a 
number of states and movements to which the physical law of equality of action and reaction cannot be applied. Even in the simple representation that is merely formed by our thought on the basis of impressions coming from without we must distinguish two aspects: 1) knowledge of external objects contained in that representation, and 2) the state of the soul produced by that representation and knowledge. The latter aspect is not subject to any mathematical calculation, for it expresses directly and uniquely the quality and value of the mood of our soul. In the one-sided striving for knowledge, we often forget that every concept enters our soul as its inner state, and we value our concepts only to the extent that they serve us as images of things. But the tree of knowledge is not the tree of life. To the spirit its life seems something more precious than its knowledge. This special, unique, and not mathematically definable life of the spirit bears the closest relation to man's heart. In it there are noticeably reflected our soul's subtle and elusive movements and states, of which we cannot form any clear representation. We never shall succeed in translating into precise knowledge the movements of joy and sorrow, of fear and hope, the feelings of goodness and love that so immediately alter the beating of our hearts. When we enjoy the contemplation of beauty in nature or art, when we are touched by the intimate sounds of music, when we marvel at the greatness of an exploit, all these more or less inspiring states are instantly reflected in the heart. This occurs with such originality and independence from the usual stream of our emotional states that human art will always complain of the inadequacy of its means to express and depict these states of the heart.

Christian ascetics often reproached reason for its sluggishness to recognize what was directly and immediately known to the heart. They often called the human mind sensual and corporal. Of course, it can seem to be such if its mediate activity is compared with the immediate and suddenly appearing revelations of truth that occur in the heart. This, however, is not to deny that the sluggish movement of reason, like a slow gait, is distinguished by definiteness and regularity, which are wanting in the too energetic movements of the heart. Nonetheless, if the light of knowledge is to become the warmth and life of the spirit, it must penetrate to the heart, where it would be able to enter into the integral mood of the soul. Thus, if truth falls upon our heart, it becomes our property, our inner treasure. Only for this treasure, and not for abstract thought, can man engage in struggle with circumstances and people. Exploit and selflessness are possible only for the heart.

From these observations we derive two points: 1) the heart can express, display, and understand absolutely distinctively states of the soul that because of their primarily spiritual and vital nature are not susceptible to the abstract knowledge of reason; 2) reason's clear and precise 
knowledge, insofar as it becomes a state of our soul and does not remain an abstract image of external objects, is revealed or makes itself felt and noticed not in the head but in the heart: it must penetrate to that depth in order to become an active and motive force of our spiritual life.

The philosophical systems of German idealism developed the doctrine of the autonomy of man's reason, or the doctrine that reason by itself, out of its own powers and resources, issues or establishes laws for all of the soul's activity. From this point of view, one would have to agree that all man's value, or the entire spiritual man, consists in thought. But the law of the soul's activities is not established by the power of the mind, is not invented by it, but lies before man as a ready, unchangeable order of the moral and spiritual life of man and mankind. Autonomy is not characteristic of human reason in any sense. Among the phenomena and actions of the soul, reason plays the role of light that illumines the life (that has not been established by it) of the human spirit and the laws of that life. The soul exists not only as this light but also as the entity that it illumines. Spiritual life is engendered in gloom and darkness prior to the light of reason, that is, in depths inaccessible to our gaze. If from the foundations of this life there arises the light of knowledge and understanding as a phenomenon following it, the viewpoint that sees the human mind as the peak and not the root of man's spiritual life is thereby fully justified.

But besides the superficial doctrine of the autonomy of the mind, a vague doctrine on the essence of the human soul is quite often encountered in psychology. Ordinarily psychology confines itself to indicating only the general generic properties of the soul, the phenomena common to every human soul. The human soul is defined by psychology as an entity that senses, represents, feels, and desires. The superiority of these phenomena in man by comparison with the corresponding phenomena in other sensibly observed creatures is explained by many factors that in any case do not reside in the original essence of the human soul and only modify its general generic character. The matter, however, must be put quite the other way around. The human soul has an original and particular content that is found or appears, unquestionably, in the general generic forms of the soul's life, which are representation, feeling, desire, and so on. Only with this assumption can one explain why in man these generic forms take on a particular and most perfect character; why they reveal his moral personality, for the expression of which we would search the soul in vain for a definite mechanism operating according to general laws; and why, finally, these finite generic forms carry a feeling and consciousness of the infinite, for which again there is no definite, special carrier or representative in the phenomena of the soul's life. But we must take one more step and posit that every individual human soul has an essential 
particularity and possesses a distinctive development, which in its turn is expressed in the general generic forms of the life of the human soul.

When it investigates the phenomena of the soul's life, science in conformance with its general method, asks according to what general conditions and laws these phenomena occur. But science's fruitful method obviously has application only to secondary, derivative phenomena of the soul's life. Every simple basis of phenomena, that is, a basis in which definite directions or forms have not yet emerged, is inaccessible to scientific analysis because such analysis presupposes a complexity and diversity of phenomena that does not exist in any simple basis. If this is true in general, then all the more should one agree that in the human soul there is something original and simple, there is a hidden man of the heart, there is a depth of the heart whose future movements cannot be calculated from general and necessary conditions and laws of the soul's life. For this very particular side of the human spirit, science cannot find general forms that would be defined for all time, forms that would be attached to this or that pair of nerves and would appear of necessity upon their movement.

When mysticism attempted to indicate the forms that would correspond completely to the spiritual content of the human heart, it could only deny all forms and expressions of the finite world and the finite spirit that are accessible to us. It seemed to mysticism that not only did the soul's lowest capabilities not correspond to the fullness and dignity of the heart's life, but that reason itself, inasmuch as it thinks in particular forms and gives birth to one thought after another in time, is a weak and imprecise expression of that life. The mystic, therefore, could only plunge into a dark feeling of unity and infinity, into the depths of the heart where every light of consciousness finally goes out. This morbid phenomenon of mysticism, which wants to escape all the finite conditions of our spiritual development and reach the final goal immediately and directly, without achieving it through laborious and gradual perfecting in time, is in any case a remarkable fact [that should be considered] when one tries to explain the life of the human soul. Mysticism is underlain by the true belief that the fullness of spiritual life we feel in the heart is not exhausted by the soul's forms that take shape under the conditions of this finite world; and is not limited to certain phenomena of the spirit that appear under temporal conditions. Opposed to mysticism is the psychological viewpoint that hopes to enumerate and define all the phenomena of the soul's life as forms that are finite and given once and for all, so that neither in them nor under them is it any longer possible to find distinctive, simple, spontaneous life that would break through unexpectedly and uncalculatedly. If this viewpoint is completely incapable of pointing out in the human soul the deepest foundations of its personality and the germ of its future life, then, on the other hand, for this viewpoint there remain and always will remain 
unsolved many phenomena of the soul that are attested by experience, for example, the portentousness of dreams, presentimental phenomena, states of clairvoyance, and particularly various mysterious forms of religious consciousness. We find the truth between the indicated extremes of mysticism and empiricism in the biblical doctrine of the heart as the focus of the life of man's soul. The heart gives birth to all the forms of the soul's life that are subject to general conditions and laws. Thus it cannot have a negative relation to them; it cannot annul them with its spontaneous impulses. The heart, however, does not transfer all its spiritual content to these forms of the soul once and for all. In the heart's depths, inaccessible to analysis, there always remains a source of new life, new movements and aspirations that go beyond the soul's finite forms and make it capable of eternity. For this reason, even in temporal but particular conditions there always remains the possibility of such unusual phenomena that go beyond the soul's usual mode of action.

The following applications can be derived from all that has been said:

1) If the heart is the focus of man's spiritual life, and aspirations, desires, and intentions arise from it spontaneously, or at least in a way that does not result with mathematical uniformity from external operative causes, then the most accurate theory of phenomena of the soul cannot determine the peculiarities and distinctions with which they are revealed in a particular soul under certain circumstances. From this we may conclude that although everything in the history of nature is subordinated to a strict mechanism allowing no exceptions, in the history of mankind, events and phenomena are possible that evidence themselves by their simple existence. The possibility of such phenomena can neither be assumed nor rejected on the basis of general laws that we know from science. When science elucidates for itself the true meaning and limits of that situation, then, perhaps, it will manage to adopt a correct attitude to the facts of religion. Hitherto it has reasoned as follows: a certain historical event, judging by strong evidence, ought to be acknowledged as real, but its occurrence contradicts general laws; hence it cannot be taken for reality. We oppose to this reasoning the following line of thought. In the original essence of man (the heart), there lies the source for phenomena bearing peculiarities that do not result from any general concept or law. On the basis of the general laws of the soul's life we can discuss only everyday, ordinary phenomena of the human spirit, phenomena determined by the usual course of things, for the laws themselves are taken or abstracted from those usual or identical phenomena. When, therefore, we encounter 
phenomena that do not fall into this ordinary group, we must investigate first of all their simple reality without concealing it by general laws, for no one has yet proved that the soul obeys the general laws with mechanical necessity like a dead and inert mass. Moreover, if it is impossible to assume that here, unlike in the sphere of physics, actions and reactions are equal, then, on the other hand, extraordinary events, as experience has shown, always occur in particular circumstances.

2) Let us suppose that all the events we observe will be in their essence such that we may, as it were, stand behind them and spy out the causes that produced them. Then we may also put ourselves behind the causes and observe the conditions and causes producing them; and thus [we might do] for every observable case. In actuality, material things do indeed possess this genuine and definite quality of the finite. But it is obvious that if everything in existence had such a derivative essence, put together from outside causes, it would not even occur to man to speak of an unconditional cause. If, however, mankind unanimously crowns all its explanations with the recognition of an unconditional first principle, this metaphysical acknowledgment is justified most of all by the nature of the human heart, behind which we can no longer stand in order to spy out still other causes from which it is put together. For this reason it possesses all the immediateness of being that is instituted by God.

3) The significance of the heart appears still more decisively in the sphere of moral activity, for we judge human actions differently depending on whether they are determined by external circumstances and corresponding considerations, or whether they result from spontaneous and free movements of the heart. Only to the latter can we properly ascribe moral value. Christian doctrine tells us that love is the source of all truly moral acts. This tenet stands in a clear causal relationship with the biblical doctrine of the heart and is justified by the principles of moral philosophy, just as the doctrine of the heart itself finds good foundations in psychology.

In place of this supreme principle of love, certain modern moralists offer us a different one: "Respect yourself, or your personality." They think this rule reveals a basis for man's morally good acts. It seems to us that moral acts can indeed result or not result from this rule, just as from rules that analytically issue from it, such as: feed yourself, protect and warm your body, exercise your memory, develop your mind and your musical talents. Moral philosophy's concept of the moral law and the doctrine of 
duty have greater significance. But the law according to which moral activity is accomplished is for that very reason not the cause of the activity, just as, for example, the law of falling bodies is not the cause of their falling. Thus it will always remain inexplicable for the rationalist viewpoint from what source there arise the deeds that turn out to conform both to moral law and to the injunction of reason. Every moral injunction of reason, its every instruction concerning what I ought to do, opens to me a prospect of deeds that are as yet only anticipated, not yet realized. "Can I accomplish those deeds? Have I the moral strength to bring about those deeds?" This is an altogether different question, about which the moral legislation of reason says nothing. The mind can indeed enjoin and command, but only when it has before it a living and inspired man rather than a dead corpse; only when its injunctions and commands are drawn from the man's nature and not thrust upon it as something alien and unrelated. For not one creature in the world comes to act lawfully from motives that are extraneous for it. The mind, as the ancients said, is the governing or ruling part of the soul. Mysticism, which plunges into the spontaneous inclinations of the heart without translating them into abstract, calm, and firm ideas or principles of the mind, contradicts the properties of the human spirit. But a governing or ruling force is not a generative force. It is a rule that extends to the moral world's content born from the deepest essence of the spirit. In its immediate form or in its first and basic appearance that content is love.

II.

In the cited article Iurkevych voices and develops his basic views. As is easily seen, in those views there are revealed not only his theoretical convictions but also his entire spiritual character. In the following article, "Iz nauki o chelovecheskom dukhe" "From the Science of the Human Spirit," 1860), Iurkevych is forced to defend his views against the theories of materialism, which were dominant then and which still have not completely lost their power over undeveloped minds. Of course, it required no effort on Iurkevych's part to prove the philosophical groundlessness of those theories, and he proved it clear as day for anyone capable of understanding. I shall note the passages in the article where the author gives voice to his personal views concerning materialism.

Ordinarily materialism speaks against the dualism that recognizes two separate natures in man-the spiritual and the corporal. But in their generally justified rejection of dualism the materialists display an extreme vagueness of basic philosophical concepts. When the Greek philosopher Plato taught that man's body is created from eternal matter having nothing 
in common with spirit, he thereby admitted metaphysical dualism both in the makeup of the world in general and in the makeup of man. The Christian world view eliminated this metaphysical dualism. It recognized matter as a product of spirit. Consequently, matter had to bear signs of its spiritual origins. In material phenomena you see form, regularity, the presence of purpose and idea. If the human spirit develops in a material body, if the perfecting of the spirit is associated with the states of the body at various ages, then the connection is not external but is determined by the meaning of human life, by its purpose or idea. Study well man's corporal organism, and you can guess what forms of his inner, spiritual life correspond to it. Study well his inner life, and you can guess what corporal organism corresponds to it. But after the metaphysical dualism is eliminated, there still remains a gnoseological dualism, a dualism of knowledge. No matter how much we talk about the unity of the human organism, we always shall cognize the human entity in two ways: through outer feelings - the body and its organs - and through inner feelingphenomena of the soul. It seems clear that thought as thought lacks spatial extension and spatial motion, lacks shape, colour, sound, odour, and taste, and lacks weight and temperature. Thus the physiologist cannot observe it with any of his corporal senses. Only inwardly, only in direct introspection does he know himself as a thinking, feeling, and aspiring creature. Have him observe the most complicated movements of the nerves. The movements, as long as they exist for outer experience, that is, as long as they are spatial movements occurring among material elements, still do not turn into sensation, representation, and thought. Thus, when it is said that the movement of a nerve is transformed into a sensation, and so on, there is always left out the agent that possesses that wondrous transforming power or has the capability and property of giving birth within itself to sensation on the occasion of the movement of a nerve. The movement, however, clearly does not itself contain the possibility or the need to be anything other than movement. Psychology requires only the recognition of that phenomenal or gnoseological difference according to which its object, as given in inner experience, has nothing in common with and is not similar to the objects of external observation. Every further question about the essence of that phenomenon, questions whether material phenomena and phenomena of the soul meet in a higher unity, and whether their differences are not the mere consequence of our limited cognition (inasmuch as it does not grasp the true, homogeneous essence of things identical with it) - all these questions belong to metaphysics and cannot be resolved by any individual science that studies these phenomena. When phenomenon is spoken of, the word either lacks meaning or signifies that the event under discussion has been altered by the forms of the sensing and understanding subject. He who, for example, explains representation 
and thought by means of the nervous process either does not understand what "phenomenon" means or regards the nerves and their movements as a thing in itself, a metaphysical, supersensible objective reality. For otherwise he would agree that the nervous process itself is only a phenomenon, that is, that its mode of appearance is already determined by the form of the representation that is as yet only desired to be produced from it. If materialism asserts that the data of inner experience also have only phenomenal significance, that is, that our inner states appear as spiritual only in our subjective understanding and in themselves are phenomena of organic life, then it must be objected that these phenomena of organic corporal life do not exist for us outside the forms of the subject who sees and understands them. Where, then, is the other subject in whose sight and understanding the very forms of the seeing and understanding subject become subjective? If phenomena are possible only for the other, where is this other in the sphere of self-observation and introspection?

On the other hand, it is indisputable that for a wave-like movement of the air to be transformed into sound and vibrations of the ether into light, a sensing entity is necessary. In it the transformation of quantitative movements into qualities of light and sound is, properly speaking, accomplished. On the very same grounds it must be acknowledged that all the qualities of an object exist not in the object as a thing in itself but in the relations of the object to the sensing subject. A phenomenon is a phenomenon because it is conditioned by the forms of a cognizing spirit's seeing and representation. That is why it is quite absurd to explain the qualities of that spirit on the basis of external phenomena, which themselves, inasmuch as they are phenomena, are conditioned by those qualities and must be explained on the basis of the original forms of the sensing and presenting spirit. It goes without saying that our five senses are by no means an unconditional revelation enabling us to sense and represent all the forces, activities, and events existent in the world. But to correctly evaluate the forces and resources of our spirit, the opposite assumption must also be made. Namely, it is quite possible that our sensible and spiritual essence possesses organs or capabilities of knowledge that do not manifest themselves only because external nature cannot act on them properly. In both cases the world of phenomena is inexplicable by itself. To explain it, we must take into account the sensing, presenting, and cognizing spirit as one of the original reasons why things appear in one way rather than another. When you speak about matter in itself, you are creating an empty abstraction that exists only in your thought. The ancient philosophers already arrived at the conviction that such pure matter, freed from ideal definitions whose content we know solely from the depths of our spirit, is nothing, non-being ( $\mu \eta$ óv). Similarly, on the other hand, the fact that the kingdom of animate creatures extends 
farther than the human kingdom has served for philosophy of all times as a basis for the doctrine that in general there is no bare materiality in the world; that everything in the world is animate and is capable not only of being but of taking pleasure in being; and that every extensive quantity is at the same time intensive, revealed in impulses and aspirations. If materialism makes use of this fact to remove the boundary between the animal world and man, it fails to explain the essential difference-while animals unquestionably possess only empirical consciousness, man is never limited to empirical consciousness. Man has and constantly manifests the ability to treat his empirical state critically and to measure what is by what should be. Man has the ability to live and develop under an idea.

Having disposed of materialism in the sphere of logic and psychology, our author crosses over into moral philosophy. Materialism correctly speaks out against the morality of formalist rigorism, which demands that we carry out general unconditional laws of duty indifferently, without feeling joy or delight in moral activity. It is true that such a morality is not in conformity with man's essence, for pleasure, satisfaction, and, consequently, welfare, happiness, or, perhaps, utility are inseparable motives of human acts. Our $I$ will always be where our activity is, regardless of whether it is moral or immoral. Our living soul will always experience definite pleasant or unpleasant sensations regardless of whether we do good or evil, pursue personal aims, or act for the happiness of others. Immoral egoism does not lie in our including ourselves and our happiness in our activity but in our excluding from that activity other people and their happiness.

But the moral system opposite to formalist rigorism, that of utilitarianism, is no more correct. That which satisfies our needs is useful. What these needs are, however, and, therefore, what objects are capable of satisfying them is something we do not determine from the idea of utility. Rather, the idea of utility changes as our needs and concepts of our worth and the purpose of our existence change. Man, like the animal, begins his existence in the pathological world of immediate quality. But neither the savage nor the educated man remains in this pathological world. He leaves it for the real world and enters the sphere of the truly existent. He makes his development dependent on the idea he has formed of his purpose and the value of things. As a consequence of the psychic relation between thoughts and ideal feelings which result from them, man feels the need or inclination to express truth in his actions, to embody the theoretically true in the morally good. Should man wish to act in accordance not only with the common good of rational creatures but also with the meaning of all that exists, this desire for unconditional moral perfection results from the ideal affects that are born from our theoretical notions of the world, its basis, and its purpose. 
Connected with the article just described are four articles under the title "Iazyk fiziologov i psikhologov" ("The Language of Physiologists and Psychologists"), published in Russkii vestnik (Russian Herald) in 1862. In them, apropos of George Henry Lewes's work on physiology, which had been published in Russian at the time, Iurkevych develops in greater detail what he voiced in the first article against materialism. These articles were preceded in time by a group of critical essays under the title "Kritikofilosofskie otryvki" ("Passages in Critical Philosophy"), ${ }^{4}$ where the author primarily examines the treatment in philosophic systems, particularly Kant's, of the basic theological doctrine of the objective reality of God. Unfortunately, these essays, which are remarkable (particularly in regard to Kant) for their rare critical perspicacity, cannot be described here because of their length.

Of greatest significance is Iurkevych's last philosophical work, "Razum po ucheniiu Platona i opyt po ucheniiu Kanta" ("Reason According to the Doctrine of Plato and Experience According to the Doctrine of Kant"). I shall set forth its fundamental ideas.

Two and only two fundamental convictions are possible for the spirit insofar as it reveals its activity in cognition. One conviction is that inherent in the spirit in general are principles enabling cognition of truth itself. The second conviction is that inherent in a human spirit connected with the general type of human corporal organization are principles enabling only the acquisition of generally valid information. Outside these convictions there remains a field for skepticism. While destroying knowledge, skepticism must, for the sake of self-consistency, doubt that it is destroying knowledge. Thus skepticism revolves helplessly in an inscrutable circle as it denies its own tenets.

The first view, which finds knowledge of truth possible, was developed in a perfection exemplary for all times by Plato in his doctrine of reason and ideas. The second view, which allows only generally valid knowledge, was developed by Kant in his doctrine on experience. Here are their respective positions:

Plato. Only the invisible supersensible essence of a thing is cognizable.

Kant. Only the visible sensible phenomenon is cognizable.

Plato The field of experience is a sphere of shadows and dreams: only reason's aspiration to the supersensible world is an aspiration to the world of knowledge.

Kant. The supersensible world is a sphere of shadows and dreams; only in the sphere of experience is knowledge possible.

\footnotetext{
4 The first two "passages" are titled "Regarding the Articles of Theological Content in the 'Philosophical Lexicon,"' and the following three "Proofs of the Objective Reality of God."
} 
Plato. We have genuine cognition when we move from ideas through ideas to ideas.

Kant. We have genuine cognition when we move from perceptions through perceptions to perceptions.

Plato. Cognition of the essence of the human spirit, its immortality, and its higher purpose deserves pre-eminently the name of science.

Kant. Cognition is not a science but a formal discipline putting us on our guard against fruitless attempts to make any assertion about the essence of the soul.

In general, if for Plato the cognition of truth is possible for pure reason, for Kant it is possible neither for pure reason nor for reason enriched by experience-in the latter case, although cognition is possible, it will not be cognition of truth but only generally valid cognition. Science has all potentialities for communicating generally valid information to us, but it does not have a single potentiality for cognizing truth. Philosophy, however, never had such brilliant victories over the realism of common sense and the positive sciences as it had in the critique of pure reason. Never with such convincing obviousness had it exposed the groundlessness of the common-sense prejudice that supposedly somewhere outside us there exist sensible objects that are completely ready-made, that are distributed in space, that change in time, that have shape and colour, that are hard and soft, fragrant and resonant, the prejudice that supposedly all these external objects and their qualities are repeated in the images of our consciousness as in a mirror as soon as we open our senses to them. We so credulously rely on experience. We justify our thoughts by comparing them with things as if these things were independent of our thoughts. Experience is not a knowledge source lying outside the cognizing subject. "Experience is the first product produced by our reason as soon as it digests the raw material of sensations." Experience and things "imagined" by experience themselves came from the workshop of human reason. The only given elements in our cognition are sensations, which do not exist anywhere except as definitions of inner feeling, for they are merely modifications of this feeling conditioned by our way of noting them one after another in time. Thus, our cognitive capabilities, since they have nothing given or existent beforehand, must from themselves produce images of the things called the data of experience. This remarkable doctrine reconciles Plato with Protagoras, and Leibnitz with David Hume. It constitutes the soul of our science and our culture. It corresponds to the social theory that hopes to found social life and the welfare of peoples not on eternal laws of truth but on the general personal consent of the citizens.

After showing Kant's idealistic positions to be true, the author, on the basis of a masterful critique that cannot be given here, finds Kant's skeptical viewpoint completely unfounded. In opposition to that point of view he 
presents his own personal opinions, joining them to Plato's doctrine. I shall give the basic features of those opinions.

Realism in all its variants hopes to cognize the essence of a thing by separating it from all its positions in the system of things and singling out the thing itself along with its original properties, not further defined by anything, from all such positions. Idealism, rejecting the very possibility of such original things, elucidates their essence, by contrast, from the reasonable position that everything has in the system of the world. This reasonable position is determined by the degree of the thing's participation in the idea and, consequently, by the place that the thing occupies as one of the members of a division of a general concept. The speculative method presumes an inner development of the concept to the forms that are given on things or in things and whose factual existence will thus be transformed into a reasonable one; or what is will be explained from what should be according to the requirement of the idea. But if the entire spirit of the true philosophical method thus resides in the conviction that the real is defined by the thinkable, this has nothing in common with the strange doctrine that the idea realizes itself, is its own executor in the world of phenomena-a doctrine that has caused so much harm to modern idealism. The idea as cause must be distinguished from the agents without which that ideal cause cannot be a cause. The eternal truth is not a force; it is truth, and all its being is thereby exhausted: "essentia ejus involvit ejus existentiam" [it embodies the essence of its existence]. It is realized in the stream of things by the action of the will that establishes the world as an executive power with respect to the idea as a legislative power.

If true being is to be ascribed to ideas, it is far from the sense in which we ascribe being to living creatures or subjects. Only in realism, which limits the entire content of our thoughts and experiences, all the living diversity of creatures and relations, to the [mechanics of the] simple and poor existence of indifferent atoms, only in realism is the category of being so simple and inert that virtually nothing can be undertaken with it. In truth, being is a tenet that takes on different meanings depending on the content of which we say that it is. Although it is true that ideas are the general and that, consequently, constant and immutable being belongs to the general, there does not follow from this modern idealism's notion that the general is what things properly speaking are. The general, an idea, truth, is reason's eternal content, which is not produced by a subject. The objective reality of living creatures capable of acting and suffering is an unconditional tenet that is not exhausted by their cognoscibility. The three spheres of true philosophy are the thinkable, the existent, and the phenomenon, that is, the kingdom of ideas, images, or eternal truth; further, the kingdom of rational creatures called to cognize that truth and to feed on it; and, finally, the spectral existence of all that is corporal. Ideas have the 
essential significance that the cosmos, which is the Son of God according to Plato, must fulfill every truth lying in ideas in order to delight in most perfect existence. Since ideas are a system of general thinkable foundations, we shall never deduce from them by a dialectical route any creature's particular individual vitality; we never shall deduce the world of the absolutely existent to which life, motion, the soul, and reason belong. Although the world's existence is possible only on general ideal foundations, its reality is not embraced by the logical idea of essence, for the spiritual principle establishing that reality is not essence but is the superessential. As in natural science, so in philosophy the basic facts cannot be deduced but must be discovered. They are basic facts precisely because there is something in them irreducible to the ideas of reason. Were the system of ideas fully transparent to us, the individual being of living and rational creatures would still seem to us an incomprehensible fate, and ideas' revelation about what is would leave us in complete ignorance regarding who is. Only in immediate inner consciousness through the reality of our own spirit is there revealed to us the superessential spirit that translates what can be (idea) into what is (reality) by means of what

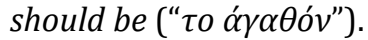

Our presentation of Iurkevych's philosophical views would be incomplete if we did not mention the particular historical, factual foundations that he sought and found for some of his most important convictions. Indeed, if a world view, as in Iurkevych's case, is not limited to the purely theoretical sphere alone but leaves the realm of logical possibilities and enters the world of reality, it must also take its foundations not from philosophical thought alone but from the facts of reality. Thus, Iurkevych's fundamental metaphysical ideas found firm support in the historical reality of religion and, it goes without saying, primarily Christianity. Similarly, his more particular ideas on the nature and purpose of the human spirit (ideas that in essence agreed fully with that same Christian doctrine) received, in his opinion, direct factual confirmation in certain particular phenomena that have appeared in recent times. I mean the phenomena of so-called spiritism. Iurkevych was convinced of their authenticity, and he expected much from them in the future. A certain particular odium lies on those phenomena in the eyes of the majority. The odium is partly justified by the fact that in the sphere of those phenomena there is much room for charlatanism and deception. It is also partly justified by the consideration that to facts there are often attached teachings that are just as banal and superficial in their content as they are exigent and impudent in their form. Iurkevych fully acknowledged this and explained it as due to the characteristics of the milieu in which the phenomena appeared. But in his eyes the inauspicious exterior of spiritism could not hide the essence of the fact. The essence of the fact, should it 
prove true, is that in a simple fashion convincing to all, it demonstrates " $a d$ oculos" [to the eyes] the truth of the Christian doctrine of the human spirit as an individual entity that possesses its own inner reality, is not completely subject to the power of external material conditions, and, therefore, after apparent death continues its development endlessly in other conditions and forms. Whether Iurkevych's belief in the authenticity of spiritist phenomena was an error and self-delusion, although a very understandable one, or whether the phenomena actually have objective cogency, the future will tell.

\section{Works Cited}

Iurkevich, Pamfil Danilovich (Iurkevych, Pamfil Danylovych). "Iazyk fiziologov i psikhologov." Russkii vestnik, vol. 38, nos. 4-6, 1862.

---. "Iz nauki o chelovecheskom dukhe." Trudy Kievskoi dukhovnoi akademii, no. 4, 1860.

---. “Kritiko-filosofskie otryvki." Trudy Kievskoi dukhovnoi akademii, Jan.-May 1861.

---. "Razum po ucheniiu Platona i opyt po ucheniiu Kanta." Moskovskie universitetskie izvestiia, no. 5, 1865-66.

---. "Serdtse i ego znachenie v dukhovnoi zhizni cheloveka." Trudy Kievskoi dukhovnoi akademii, no. 1, 1860. 